\title{
The RANK/RANKL/OPG system in tumorigenesis and metastasis of cancer stem cell: potential targets for anticancer therapy
}

This article was published in the following Dove Press journal:

OncoTargets and Therapy

27 July 2017

Number of times this article has been viewed

\author{
Mekonnen Sisay' \\ Getnet Mengistu' \\ Dumessa Edessa ${ }^{2}$ \\ 'Department of Pharmacology and \\ Toxicology, ${ }^{2}$ Department of Clinical \\ Pharmacy, School of Pharmacy, \\ College of Health and Medical \\ Sciences, Haramaya University, Harar, \\ Eastern Ethiopia
}

\begin{abstract}
The molecular triad involving receptor activator of nuclear factor $\mathrm{k} \beta$ (RANK)/ RANK ligand (RANKL)/osteoprotegerin cytokine system has been well implicated in several physiological and pathological processes including bone metabolism, mammary gland development, regulation of the immune function, tumorigenesis and metastasis of cancer stem cell, thermoregulation, and vascular calcification. However, this review aimed to summarize several original and up-to-date articles focusing on the role of this signaling system in cancer cell development and metastasis as well as potential therapeutic agents targeting any of the three tumor necrotic factor super family proteins and/or their downstream signaling pathways. The RANK/RANKL axis has direct effects on tumor cell development. The system is well involved in the development of several primary and secondary tumors including breast cancer, prostate cancer, bone tumors, and leukemia. The signaling of this triad system has also been linked to tumor invasiveness in the advanced stage. Bone is by far the most common site of cancer metastasis. Several therapeutic agents targeting this system have been developed. Among them, a monoclonal antibody, denosumab, was clinically approved for the treatment of osteoporosis and cancer-related diseases
\end{abstract}

Keywords: cancer, RANK, RANKL, OPG, RANK/RANKL/OPG system, therapeutic, tumor

\section{Introduction}

Overview of receptor activator of nuclear factor $k \beta$ (RANK)/RANK ligand (RANKL)/osteoprotegerin (OPG) signaling system

The molecular triad involving RANK/RANKL/OPG cytokine system has been observed to influence various physiological and pathological processes throughout the body. These include bone modeling and remodeling, mammary gland development, tumor cell development and migration, and modulation of adaptive immunity (Figure 1). ${ }^{1-4}$ The role of this signaling system has been well emphasized in bone where RANKL/ RANK signaling mediates osteoclastogenesis and bone resorption via paracrine signaling between osteoblast (RANKL) and osteoclast (RANK) cells. OPG produced by osteoblast and stromal cells acts as a soluble decoy receptor for RANKL and hence prevents osteoclast differentiation and activation by interfering with RANKL-RANK interaction. ${ }^{1}$ RANK is also constitutively expressed in mammary epithelial tissues where RANKL works through RANK to provide proliferative and survival signals and thereby promotes the final stages of lactating mammary gland development. ${ }^{5}$ It has also been shown to be involved in thermoregulation signaling in females (linked with
Correspondence: Mekonnen Sisay Department of Pharmacology and Toxicology, School of Pharmacy, College of Health and Medical Sciences, Haramaya University, PO Box 235, Harar Eastern Ethiopia

Tel +25 I 920212135

Fax +25 I 25666808 I

Email mekonnensisay2003@yahoo.com hereby accept the Terms. Non-commercial uses of the work are permitted without any further permission from Dove Medical Press Limited, provided the work is properly attributed. For permission for commercial use of this work, please see paragraphs 4.2 and 5 of our Terms (https://www.dovepress.com/terms.php). 


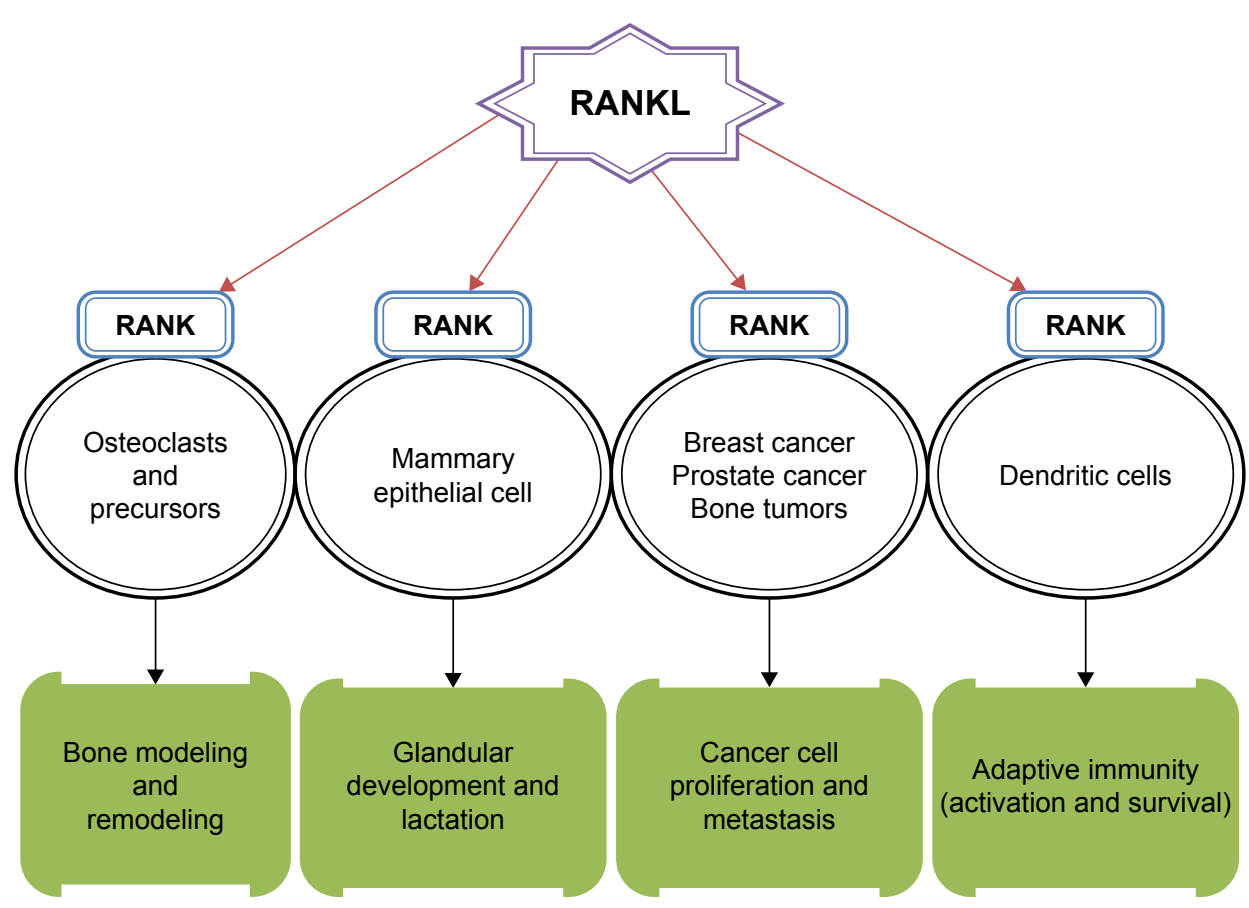

Figure I The role of RANK/RANKL signaling system in various physiological and pathophysiological processes. Abbreviations: RANK, receptor activator of nuclear factor $k \beta$; RANKL, RANK ligand.

ovarian sex hormones) possibly via the $\mathrm{COX}_{2}-\mathrm{PGE}_{2} / \mathrm{EP}_{3} \mathrm{R}$ pathway, vascular calcification, and atherosclerosis by cross talking with the renin-angiotensin system. ${ }^{6-10}$

\section{Methods}

In this review, both open access scholarly sources and subscription based journals were utilized for the study. Legitimate databases and indexing services including directory of open access journals, PubMed, PubMed Central, Medline, Scopus, and ProQuest were considered for the collection of articles related to the topic of interest. Other supplementary sources such as Google Scholar, WorldCat, and ResearchGate were also used for extensively collecting updated and sufficient information on this topic. For subscription based journals, however, Hinari: World Health Organization for developing countries was used to access such journals (eg, Elsevier journals, subscribed journals in PubMed, Science Direct, etc.). The primary key terms used during data collection were "RANK," "RANKL," "OPG," "RANK/RANKL/OPG system," "cancer," "tumor," and "therapeutic." In each of the databases and web directories, Boolean logic (AND, OR) was routinely applied to connect the key terms. What is more, truncation and alternative terms were also employed to expand the chance of obtaining related articles to the topics of interest. Based on these key terms and following in-depth screening of the relevance of each and every article for the topic, only articles that are highly relevant to this review were included and duplicated articles were excluded from the study in advance. Excluding the background, 73 references were filtered for the body of this review. Coming to the timing distribution of references cited, the majority of references, 52 (71.23\%), were published from 2010 to 2017. Data collection was conducted from September 2016 to April 2017.

\section{Overview of RANK/RANKL/OPG system and cancer}

Primary tumors will commonly metastasize into bone. Tumors such as breast and prostate cancers typically have a greater chance of inducing secondary cancers within bone. ${ }^{11}$ Based on Stephen Paget's seed and soil theory, the bone microenvironment provides a conducive area (fertile soil) in which the seeds (secondary tumors) can easily grow in. RANK and RANKL have been known to be involved in cancer cell migration and development in bone. ${ }^{12}$ Secondary tumors within the bone will secrete several growth factors and cytokines which stimulate osteoblast cells. Upon stimulation, osteoblast cells increase the expression and release of RANKL which in turn acts either on the RANK receptor found on the osteoclast cells or soluble decoy receptor (OPG) that circulates in body fluids. RANKL-RANK interaction activates osteoclasts to further release growth factors such as tumor growth factor $\beta$ and insulin-like growth factor 1 from the bone matrix which in turn stimulate parathyroid 
hormone-related peptide production and promote tumor growth. This interaction between tumor cells and the bone microenvironment results in a vicious cycle of bone destruction and tumor growth. Generally, skeletal-related events (SREs) are used to describe a collection of adverse events associated with bone metastases. SREs include pathologic fractures that require surgery or chemotherapy, spinal cord compression, and less frequently malignant hypercalcemia. ${ }^{11,13,14}$ RANKL was also observed to be more accurate than conventional markers in the breast cancer subgroup, and was a better predictor of bone progression than N-terminal telopeptides of type I collagen. The study suggested that RANKL could serve as an accurate marker of bone response in metastatic patients. High RANKL levels may identify patients with a shift in bone homeostasis toward bone resorption. ${ }^{15}$

\section{The role of RANK/RANKL/OPG system in solid cancers \\ Primary bone tumors}

Malignant tumors of the bone can be either primary tumors or secondary (metastasized) tumors. Primary tumors include osteosarcoma, multiple myeloma, and giant cell tumor of the bone (Table 1). Osteosarcoma is the most common primary malignant tumor of the bone. ${ }^{16}$

This triad system also plays a significant role in various solid malignancies that are capable of metastasizing to bone. These include breast cancer, prostate cancer, and lung cancer, among others. ${ }^{22}$ This triad system is by far strongly implicated in the physiology of mammary gland development and pathogenesis of breast cancer cells. ${ }^{5,23,24}$ The role of the RANK/RANKL/OPG triad system goes beyond involvement of breast cancer pathogenesis. The second most common target is prostate cancer. It has also been implicated in the pathogenesis of several and rare malignant tumors such as lung cancer, renal cell carcinoma, hepatocellular carcinoma, and melanoma (Table 2). ${ }^{22,25}$

The regulatory function of RANKL is one of the key factors in progesterone-induced proliferation of the breast. Progesterone has a direct action on progesterone receptor (PR) expressing cells but PR-negative cells are affected indirectly through RANKL-induced paracrine actions leading to the proliferation of mammary epithelial PR-negative cells. RANK induces epithelial to mesenchymal transition and stemness in human mammary epithelial cells and promotes tumorigenesis and metastasis. ${ }^{26}$ RANKL stimulation of RANK expressing cells increased multidrug resistance protein 1, breast cancer resistance protein, and lung resistance protein 1 expression and decreased Bim expression through various signaling molecules. These results indicate that the RANK/ RANKL system induces chemoresistance through the activation of multiple signal transduction pathways. ${ }^{27}$ What is more, expression of RANKL was observed during pregnancy. This evidence suggests that RANKL can be used as a potential breast cancer therapeutic target particularly in young women and pregnancy-associated tumors. RANKL/RANK has also been shown to control breast cancer 1 gene mutation-driven mammary tumors. Besides, the E3 ubiquitin ligase Cbl-b protein has been shown to improve the prognosis of $\mathrm{RANK}^{+}$ breast cancer patients via inhibiting RANKL-induced cancer cell migration and metastasis (Figure 2). ${ }^{28-31}$

\section{Other solid cancers}

RANKL, RANK, and OPG were variably expressed in tumors of the thyroid, including papillary carcinomas, medullary carcinomas, and macrovascular adenomas. ${ }^{60}$ Increased

Table I The role of RANKL/RANK/OPG system in primary malignant tumors of the bone

\begin{tabular}{|c|c|c|}
\hline $\begin{array}{l}\text { Primary bone } \\
\text { tumors }\end{array}$ & RANKL/RANK/OPG system and its role in tumorigenesis & References \\
\hline \multirow[t]{3}{*}{ Osteosarcoma } & $\begin{array}{l}-\uparrow \text { RANKL/OPG ratio was observed in the serum of patients with } \\
\text { osteosarcoma }\end{array}$ & Grimaud et al ${ }^{17}$ \\
\hline & $\begin{array}{l}\text { - In experimental animals, OPG treatment achieved not only the prevention } \\
\text { of osteosarcoma-induced osteolysis but also the inhibition of associated } \\
\text { tumor development that improved the survival rate in treatment groups }\end{array}$ & Lamoureux et al ${ }^{18}$ \\
\hline & $\begin{array}{l}\text { - RANKL blockade has been shown to prevent and treat aggressive } \\
\text { osteosarcomas }\end{array}$ & Chen et $\mathrm{al}^{19}$ \\
\hline Multiple myeloma & $\begin{array}{l}\text { Deregulation of the triad system (expression of more RANKL and/or more } \\
\text { lysosomal degradation of OPG) enhances osteoclastogenesis }\end{array}$ & Pearse et $\mathrm{al}^{20}$ \\
\hline \multirow[t]{2}{*}{ GCTB } & $\uparrow$ RANKL/OPG ratio was also observed in GCTB & \\
\hline & $\begin{array}{l}\text { The stromal cells within GCTB had increased RANKL/OPG ratio compared } \\
\text { to that of non-osteolytic bone tumors }\end{array}$ & Lewin and Thomas ${ }^{21}$ \\
\hline
\end{tabular}

Note: $\uparrow$, increased, high.

Abbreviations: GCTB, giant cell tumor of the bone; OPG, osteoprotegerin; RANK, receptor activator of nuclear factor k $\beta$; RANKL, RANK ligand. 
Table 2 The role of RANK/RANKL/OPG system in the development and metastasis of solid cancers

\begin{tabular}{ll}
\hline Solid cancers & Methods \\
\hline Breast cancer & $\begin{array}{l}\text { RANK and RANKL gene knockout in mice models } \\
\text { (in vivo study) }\end{array}$
\end{tabular}

Site directed mutagenesis (in mice model) and RANKL blockage

RANK gene knockout or loss of function mutation in mice model and RANKL treatment

In vitro studies (MDA-MB-436/23I breast cancer cells)

Cancer patients (correlation of Kaplan-Meier survival analysis with serum samples of RANK and OPG)

Experimental investigations (breast cancer patients) plus in vitro study (RANKL producing CD4 ${ }^{+}$CD25 $5^{+}$T-cells)

4TI and NMuMG cells (ATCC) and MCF 7 cells (lentiviral infection to induce tumorigenesis in normal cells)

In vitro study on human MDA-MB-23 I breast cancer cell lines (MDA-23I-RANK cells)

Primary breast cancer samples from the neoadjuvant GeparTrio study (in vitro) plus in vivo experimental study (mice model)

A nested case-control study

Human breast epithelial cells with Brcal haploinsufficiency cell

Observed molecular mechanisms and effects

- Immature lobuloalveolar development (disorganized mammary gland structure) and disabled milk production

- RANKL-driven hormone (progesterone) dependent proliferation, survival, and expansion of mammary stem cell could each contribute to mammary cancer initiation, progression, and recurrence

- Gain of function mutation of RANK signaling resulted in $\uparrow$ formation of pre-neoplasias and tumors, whereas inhibition of RANKL $\downarrow$ tumorigenesis

- $\downarrow$ and retarded progestin (MPA)-driven breast cancer

- RANKL addition $\downarrow$ cell death in response to antitumor antibiotics and irradiation

- $\uparrow$ Expression of RANK, RANKL, and OPG. OPG acts as a decoy receptor for TRAIL and thereby inhibits apoptosis of a range of tumor cells (survival signal for breast cancer cells)

- $\downarrow$ Expression of serum OPG $\rightarrow$ better overall survival of patients (quantity of life in years)

- $\uparrow$ RANK and $\downarrow$ OPG expression $\rightarrow \uparrow$ metastasis of breast cancer to bone

- However, contradictory results on OPG were observed

- In bone, OPG reduces bone loss (osteolysis) due to breast cancer metastasis; however, in breast cancer, OPG $\downarrow$ apoptosis of cancer cell ( $\uparrow$ survival and invasiveness)

- High expression of $\mathrm{CD}^{+} \mathrm{CD} 25^{+} \mathrm{FoxP} 3^{+}$Treg cells

$\uparrow$ aggressiveness of breast cancer phenotype and $\uparrow$ RANKL production (major source)

- In $\mathrm{ER}^{-}$and $\mathrm{PR}^{-}$breast cancer cells $\rightarrow$ more expression of RANK mRNA levels and generally have poorer prognosis and high degree of invasiveness than controls. Moreover, RANK overexpression has also been demonstrated to induce epithelial to mesenchymal transition and stemness

- MDA-MB-23I cells with high RANK expression resulted in greater metastatic growth rate. However, MDA-MB-23I cells with low RANK level primarily remain in situ

- Administration of RANKL for these cells

- $\Uparrow$ expression of multiple genes associated with cell invasive behavior (including several matrix metalloproteinases and other genes that can be considered as a bone metastasis gene signature

- Pharmacologic inhibition of RANKL attenuates tumor development and metastasis in mice

- High RANK expression

- Higher sensitivity to chemotherapy but a higher risk of relapse and death

- Higher concentrations of OPG were associated with increased risk of $\mathrm{ER}^{-}$breast cancer but less likely in $\mathrm{ER}^{+}$type

- Denosumab has been proposed to interfere with the cross talk between RANKL producing sensor cells and cancer initiating $\mathrm{RANK}^{+}$responder cells that reside within premalignant tissues of Brca I-mutation carriers
References

Fata et $\mathrm{al}^{5}$

Dougall ${ }^{23}$

Gonzalez-Suarez et $\mathrm{al}^{24}$

Schramek et al ${ }^{32}$

Emery et $\mathrm{al}^{33}$

Holen et $\mathrm{al}^{34}$

Santini et al;22

Owen et $\mathrm{al}^{35}$

Weichhaus et $\mathrm{a}^{36}$

Tan et $\mathrm{al}^{37}$

Palafox et al; 38

Tsubaki et al $^{39}$

Blake et $\mathrm{al}^{40}$

Pfitzner et $\mathrm{al}^{4}$

Fortner et $\mathrm{al}^{42}$

Cuyàs et al ${ }^{43}$

(Continued) 
Table 2 (Continued)

\begin{tabular}{|c|c|c|c|}
\hline Solid cancers & Methods & Observed molecular mechanisms and effects & References \\
\hline & Case control study & $\begin{array}{l}\text { - Brcal-mutation carriers had lower mean values of free } \\
\text { serum OPG, in particular, in Brcal-mutation carriers } \\
(P=0.018) \text { compared with controls }\end{array}$ & $\begin{array}{l}\text { Widschwendter } \\
\text { et al }{ }^{44}\end{array}$ \\
\hline & Human case reports & $\begin{array}{l}\text { - RANK and RANKL coexpression is associated with } \\
\text { poor RFS and OS in patients with TNBC }\end{array}$ & Reyes et $\mathrm{a}^{45}$ \\
\hline & $\begin{array}{l}\text { Surgical biopsy sample of prostate cancer patients } \\
\text { and in vitro studies (normal human prostate cells, } \\
\operatorname{PrEC} \text { and human prostate cancer cell lines-LNCaP, } \\
\text { DU- } 145 \text {, and PC- } 3 \text { cells) }\end{array}$ & $\begin{array}{l}\text { - In prostate cancer cells, } \uparrow \text { RANK, RANKL, and OPG } \\
\text { expression was observed indicating more aggressive } \\
\text { and advanced stage; however, normal cells have } \\
\text { negligible expression of these proteins }\end{array}$ & Chen et $\mathrm{a}^{46}$ \\
\hline \multirow[t]{6}{*}{ Prostate cancer } & $\begin{array}{l}\text { Comparative study on hormone-insensitive } \\
\text { prostate cancer cell lines (PC-3 and DU-I45) and } \\
\text { hormone-sensitive cell line (LNCaP) under the } \\
\text { same conditions }\end{array}$ & $\begin{array}{l}\text { - OPG is considered as a survival factor for prostate } \\
\text { cancer cells by blocking TRAIL }\end{array}$ & Holen et $\mathrm{al}^{47}$ \\
\hline & Metastatic cancer cell models & $\begin{array}{l}\text { - RANKL } \rightarrow \uparrow \text { IKK } \alpha \text { (active) and } \downarrow \text { Maspin (metastasis } \\
\text { suppressor protein) leading to disease progression and } \\
\text { tumor invasiveness }\end{array}$ & Luo et $\mathrm{al}^{48}$ \\
\hline & $\begin{array}{l}\text { ARCaP(E)/ARCaP(M) prostate cancer model and } \\
\text { LNCaP clones overexpressing Snail in a stable } \\
\text { manner }\end{array}$ & $\begin{array}{l}\text { - RANKL expression upregulates mesenchymal- } \\
\text { associated genes (morphogenic conversion from } \\
\text { epithelial to mesenchymal type) } \rightarrow \text { more tumor } \\
\text { invasiveness (loss of cell to cell adhesion) }\end{array}$ & $\begin{array}{l}\text { Odero-Marah } \\
\text { et } \mathrm{al}^{49}\end{array}$ \\
\hline & $\begin{array}{l}\text { In murine model of prostate cancer (PC-3) cells, } \\
\text { observation of the effect of RANKL inhibitor and/or } \\
\text { antimitotic agent (docetaxel) }\end{array}$ & $\begin{array}{l}\text { - Inhibition of RANKL significantly reduced pathologic } \\
\text { osteolysis and } \Uparrow \text { antitumor effect of docetaxel leading } \\
\text { to } \downarrow \text { skeletal tumor burden and prolonged survival }\end{array}$ & Miller et $\mathrm{al}^{50}$ \\
\hline & $\begin{array}{l}\text { Case control study (enzyme-linked immunosorbent } \\
\text { assay) }\end{array}$ & $\begin{array}{l}\text { - Higher OPG and PSA concentrations have been } \\
\text { observed in metastatic bone patients' sera. It seems } \\
\text { that elevated levels of serum OPG in patients with } \\
\text { prostate cancer reflect the bone metastatic extent } \\
\text { and may potentially be used in metastatic patients' } \\
\text { follow-ups }\end{array}$ & $\begin{array}{l}\text { Siampanopoulou } \\
\text { et } \mathrm{a}^{51}\end{array}$ \\
\hline & $\begin{array}{l}\text { Experimental study on murine model (non- } \\
\text { castration, castration, and castration + OPG groups) }\end{array}$ & $\begin{array}{l}\text { - The mechanisms of RANK/RANKL signaling are } \\
\text { involved in the ADT-induced acceleration of bone } \\
\text { metastasis in castration-insensitive prostate cancer }\end{array}$ & Takayama et al ${ }^{52}$ \\
\hline \multirow[t]{3}{*}{ Lung cancer } & $\begin{array}{l}\text { Model of lung cancer (human lung cancer } \\
\text { [A549] cells) }\end{array}$ & - RANKL $\rightarrow$ upregulation ICAM-I $\rightarrow \uparrow$ tumor migration & Chen et $\mathrm{a}^{53}$ \\
\hline & $\begin{array}{l}\text { Experimental investigation in human patients and } \\
\text { case reports }\end{array}$ & $\begin{array}{l}\text { - Denosumab ameliorated ALK-induced lung cancer } \\
\text { - Inhibition of RANK } \rightarrow \downarrow \mathrm{PI} 3 \mathrm{~K} \text { activation } \\
\rightarrow \text { downregulation of } \mathrm{Akt} / \mathrm{Pk} \beta \text { (ALK fusion protein } \\
\text { downstream signaling) }\end{array}$ & $\begin{array}{l}\text { Curioni- } \\
\text { Fontecedro } \\
\text { et } \text { a }^{54}\end{array}$ \\
\hline & $\begin{array}{l}\text { (NSCLC) bone metastasis models } \\
\text { Radiography, longitudinal bioluminescent imaging, } \\
\text { and histological analyses }\end{array}$ & $\begin{array}{l}\text { - Recombinant version of OPG (OPG-Fc) } \downarrow \text { osteolytic } \\
\text { lesions and significantly reduce skeletal tumor burden in } \\
\text { NSCLC cells }\end{array}$ & Miller et $\mathrm{a}^{55}$ \\
\hline $\mathrm{RCC}$ & $\begin{array}{l}\text { Histopathologic study of RCC patients with } \\
\text { RTQPCR }\end{array}$ & $\begin{array}{l}\text { - In clear cell RCCs, } \Uparrow \text { RANK mRNA expression } \\
\text { 个 RANK/OPG ratio and low disease-free survival } \\
\text { were observed }\end{array}$ & Mikami et a ${ }^{56}$ \\
\hline $\mathrm{HCC}$ & Case report in virus-induced $\mathrm{HCC}$ patients & $\begin{array}{l}\text { - In hepatitis } C \text { virus and hepatitis } B \text { virus-induced } \mathrm{HCC} \\
\text { - RANKL expression } \rightarrow \text { invasiveness and metastasis to } \\
\text { bone }\end{array}$ & Sasaki et $\mathrm{al}^{57}$ \\
\hline Melanoma & $\begin{array}{l}\text { In vivo study on malignant tumor of melanocytes } \\
\text { In vivo study targeting the thymus gland (AIRE) }\end{array}$ & $\begin{array}{l}\text { - RANKL blockage } \rightarrow \downarrow \text { bone metastasis and morbidity } \\
\text { - RANKL blockage } \rightarrow \text { depletes AIRE that expresses } \\
\text { MTEC and TSA expression in the thymus gland leading } \\
\text { to a window of defective negative selection, rescue } \\
\text { melanoma-specific T-cells from thymic deletion and } \\
\uparrow \text { host survival secondary to tumor challenge }\end{array}$ & $\begin{array}{l}\text { Jones et } \mathrm{a}^{58} \\
\text { Khan et a }{ }^{59}\end{array}$ \\
\hline
\end{tabular}

Notes: $\uparrow$, increased, unregulated; $\downarrow$, decreased, downregulated, attenuated.

Abbreviations: ADT, androgen deprivation therapy; AIRE, autoimmune regulator gene; ALK, anaplastic lymphoma kinase; ATCC, American type cell culture; ER, estrogen receptor; HCC, hepatocellular carcinoma; ICAM-I, intercellular adhesion molecule-I; MTEC, medullary thymic epithelial cells; NSCLC, non-small-cell lung cancer; OPG, osteoprotegerin; OS, overall survival; PkB, protein kinase B; PR, progestin receptor; PSA, prostate-specific antigens; RANK, receptor activator of nuclear factor k $\beta$; RANKL, RANK ligand; RCC, renal cell carcinoma; RFS, relapse-free survival; RTQPCR, real-time quantitative polymerase chain reaction; TNBC, triple-negative breast cancer; TRAIL, tumor necrosis factor-related apoptosis inducing ligand; Treg, Regulatory T-cells; TSA, tumor-specific antigens. 


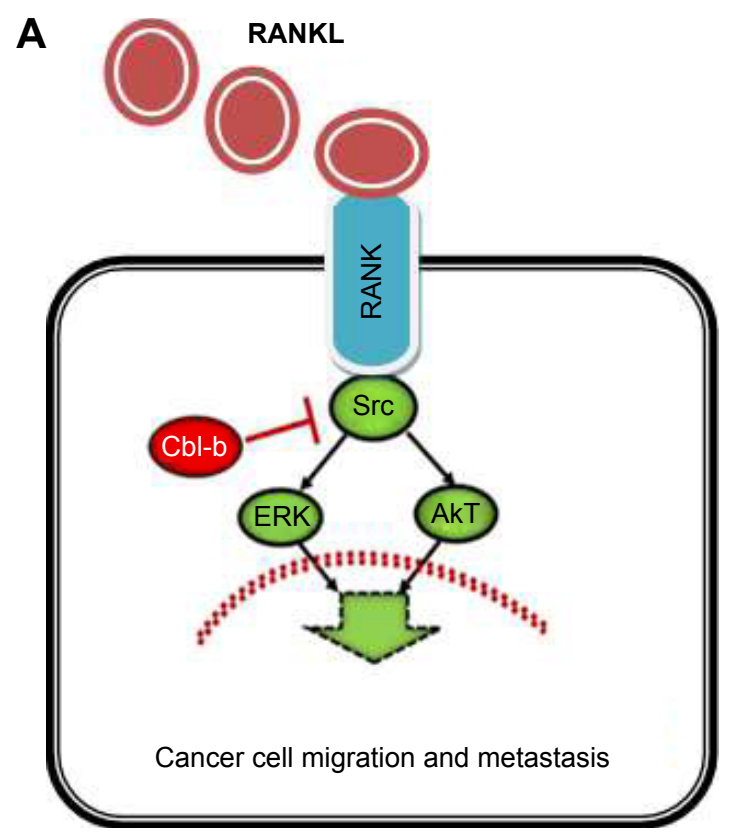

B

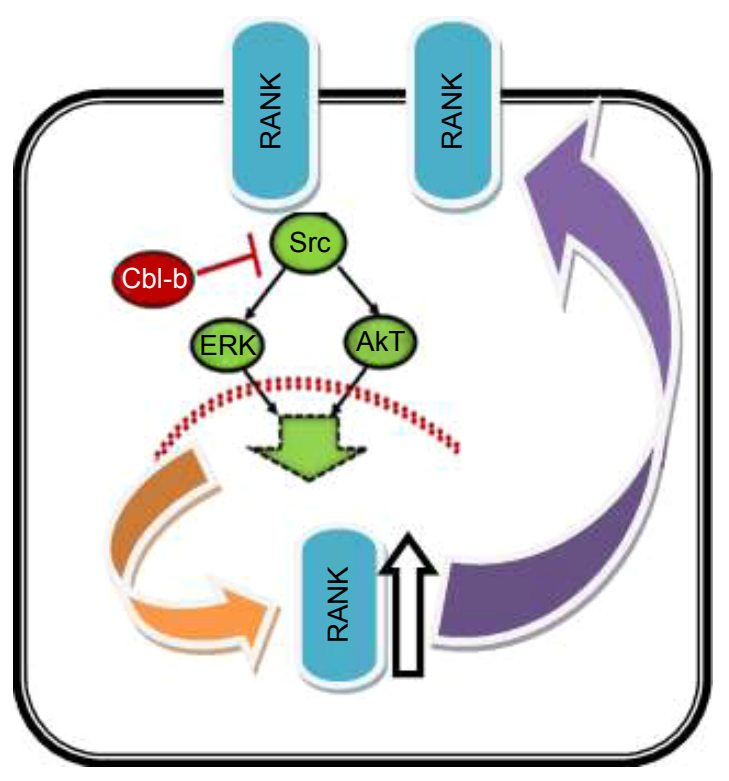

Figure 2 The role of Cbl-b in RANKL-induced breast cancer cell migration and metastasis.

Notes: (A) Cbl-b protein inhibited RANKL-induced breast cancer cell migration and metastasis; (B) Cbl-b downregulated RANK protein expression by negatively regulating the Src-Akt/ERK pathway.

Abbreviations: ERK, extracellular signal regulated kinase; RANK, receptor activator of nuclear factor k $\beta$; RANKL, RANK ligand.

serum OPG has also been correlated with poor prognosis in gastric carcinoma ${ }^{61}$ and bladder carcinoma. ${ }^{62}$ RANK overexpression was also considered as a novel esophageal cancer marker. ${ }^{63}$

\section{Nonsolid cancers}

Beyond its role in the pathogenesis of several primary and secondary solid malignant tumors, this signaling system has been known to be involved in certain nonsolid cancers such as chronic lymphocytic leukemia and acute myeloid leukemia (AML).

\section{Leukemia}

Expression of RANKL was also observed in chronic lymphocytic leukemia and has been known to induce inflammatory cytokines involved in the disease pathogenesis (tumor necrosis factor [TNF], interleukin [IL]-6, and IL-8). A novel Fc-engineered RANK fusion protein was shown to induce natural killer (NK) cell-mediated antitumor immunity against RANKL expressing targets. ${ }^{12}$ Besides, RANKL influences the interaction of NK and AML cells by mediating a feedback loop that involves the release of factors by the latter which upregulates RANK on the former. In addition to the immediate inhibitory effects of RANKL-induced factors, RANK is readily available to interact with RANKL expressed by AML cells. This process leads to the activation of a bidirectional signal transduction cascade that causes the delivery of RANK-mediated inhibitory signals to NK cells and perpetuates RANKL reverse signaling process in AML cells. ${ }^{64}$

The adhesion of the freshly isolated lymphoma B cells to bone marrow stromal cells or freshly isolated lymphoma stromal cells inhibited B cell spontaneous apoptosis in culture. This inhibition of apoptosis correlated with decreased cleavage of caspase-3/8 and increased activation of canonical and noncanonical nuclear factor kappa B signaling pathway. ${ }^{65}$ Prognostic analysis revealed a higher probability of overall survival in cases with lower RANKL expression ( $<1.6$ and $\geq 1.6,15.6$ vs 12.2 months, $P=0.008$, hazard ratio $0.36, P=0.008$ ). The study revealed that RANKL is a promising marker to forecast patients' prognosis in AML. ${ }^{66}$

\section{Potential therapeutic approaches}

Considering this molecular triad system as a hot spot in the area of oncology research, several therapeutic agents have been developed over the last decade. These include humanized monoclonal antibodies, herbal medicines, RNA interference technology, and proteolytic enzymes, among others (Table 3). 
Table 3 Potential therapeutic agents targeting this signaling system

\begin{tabular}{|c|c|c|c|}
\hline Therapeutic classes & Examples & Molecular mechanisms and effects & References \\
\hline \multirow[t]{4}{*}{$\begin{array}{l}\text { Monoclonal antibodies } \\
\text { (humanized) }\end{array}$} & \multirow[t]{4}{*}{ Denosumab } & $\begin{array}{l}\text { - It binds with RANKL (antigen-antibody interaction) and } \\
\text { interrupts RANK-RANKL interaction. It mimics the } \\
\text { antagonistic effect of OPG but it does not affect TRAIL } \\
\text { and thereby prevents cancer cell survival and migration. } \\
\text { It was approved by FDA for treatment }\end{array}$ & $\begin{array}{l}\text { Kostenuik et al,;67 } \\
\text { Peddi et al }{ }^{68}\end{array}$ \\
\hline & & $\begin{array}{l}\text { - Prolonged treatment with denosumab has sustained } \\
\text { activity in GCTB, with a mild toxicity profile }\end{array}$ & Palmerini et al ${ }^{69}$ \\
\hline & & $\begin{array}{l}\text { - Systemic therapy inhibits bone resorption by osteoclast- } \\
\text { like giant cells }\end{array}$ & van der Heijden et al ${ }^{70}$ \\
\hline & & $\begin{array}{l}\text { - Notably, proliferation was markedly reduced in breast } \\
\text { biopsies from Brca I-mutation carriers that were treated } \\
\text { with denosumab }\end{array}$ & Nolan et $\mathrm{al}^{71}$ \\
\hline $\begin{array}{l}\text { Osteoprotegerin-like } \\
\text { peptidomimetics }\end{array}$ & OP3-4 & - Selective inhibitors of RANKL without affecting TRAIL & Heath et $\mathrm{al}^{72}$ \\
\hline RANK receptor inhibitors & - & - Targets the cytoplasmic motifs of RANK receptor & Kim et $\mathrm{al}^{73}$ \\
\hline Peptide RANK antagonists & $\begin{array}{l}\text { Novel nonapeptide } \\
\text { series }\end{array}$ & - Targets hinge region of RANK receptor & Téletchéa et $\mathrm{al}^{74}$ \\
\hline Proteolytic enzymes & Enteropeptidase & - Cleavage of RANK on NEEDK amino acid sequences & Zhao et $\mathrm{al}^{75}$ \\
\hline RANKL targeting peptides & - & - Based on the molecular modeling (3D structure) of OPG & Naidu et a $\mathrm{l}^{76}$ \\
\hline RNA interference technology & Small hairpin RNAs & - Targets interruption of RANK expression & Ma et $\mathrm{al}^{77}$ \\
\hline Organic acid derivatives & Strontium ranelate & - $\uparrow$ OPG mRNA expression and secretion & Brennan et $\mathrm{al}^{78}$ \\
\hline Anti-inflammatory drugs & Chloroquine & $\begin{array}{l}-\downarrow R A N K L \text { expression } \\
-\uparrow \text { TRAF3 production }\end{array}$ & Xiu et al $^{79}$ \\
\hline Herbal medicines & Jolkinolide B & $\begin{array}{l}\text { - Root of Euphorbia fischeriana (source) } \downarrow \text { RANKL-induced } \\
\text { activation of NF- } \kappa \text { B by suppressing RANKL-mediated } \\
\text { I } \mathrm{KB} \alpha \text { degradation }\end{array}$ & Ma et al ${ }^{80}$ \\
\hline & WEAT & $\begin{array}{l}\text { - Inhibited RANKL-induced activation of JNK, NF- } \mathrm{KB} \text {, and } \\
\text { CREB leading to suppression of the induction of c-Fos } \\
\text { and NFATcl (key transcription factors for osteoclast } \\
\text { differentiation) }\end{array}$ & Ha et $a^{81}$ \\
\hline Other agents & Afatinib & $\begin{array}{l}\text { - It significantly suppresses RANKL-induced osteoclast } \\
\text { formation in BMMs. Consistently, it inhibits the } \\
\text { expression of osteoclast marker genes, whereas it } \\
\text { upregulates the expression of negative modulator } \\
\text { genes. The bone resorbing activity of osteoclasts is also } \\
\text { abrogated by afatinib. In addition, it inhibits RANKL- } \\
\text { mediated Akt/protein kinase B and c-Jun N-terminal } \\
\text { kinase phosphorylation }\end{array}$ & Ihn et $a^{82}$ \\
\hline
\end{tabular}

Notes: $\uparrow$, increased, unregulated; $\downarrow$, decreased, downregulated, attenuated.

Abbreviations: BMM, bone marrow macrophages; CREB, cAMP response element-binding protein; FDA, US Food and Drug Administration; GCTB, giant cell tumor of the bone; JNK, Jun N-terminal kinase; NF- KB, nuclear factor kappa B; OPG, osteoprotegerin; RANK, receptor activator of nuclear factor k $\beta$; RANKL, RANK ligand; WEAT, water extract of Acer tegmentosum; 3D, three-dimensional; TRAIL, tumor necrosis factor-related apoptosis inducing ligand; NEEDK, aspargine, glutamic acid, glutamic acid, aspartic acid and lysine; TRAF, tumor necrosis factor receptor associated factor.

\section{Conclusion}

The role of the RANK/RANKL/OPG system is well emphasized in this review article. Beyond regulation of many biological functions throughout the body, the system has a key role in the pathophysiology of various disorders. This triad system can be considered as a hot spot in the area of experimental oncology. This review revealed that the system is strongly implicated in the development of mammary gland structures and tumorigenesis of lobuloalveolar cells of the breast. It has also been shown to take part in the pathogenesis of several solid and nonsolid cancer types including prostate cancer, lung cancer, renal cell carcinoma, melanoma, and leukemia. What is more, the system is highly associated with tumor invasiveness and metastasis. Considering the role of this triad system in cancer cell development and metastasis, scientists are striving to discover therapeutic agents targeting these TNF-related proteins (RANK, RANKL, and OPG) and their downstream signaling pathways for better treatment of cancer and osteoporosis (bone osteolysis) in the near future. Some of these agents include denosumab, enteropeptidase enzymes, small hairpin RNAs, and Jolkinolide B. 


\section{Author contributions}

All authors contributed toward conception of the original idea, data analysis, drafting and critically revising the paper and agree to be accountable for all aspects of the work . MS also prepared the final manuscript for publication.

\section{Disclosure}

The authors report no conflicts of interest in this work.

\section{References}

1. Hofbauer LC, Heufelder AE. Role of receptor activator of nuclear factor- $\kappa \mathrm{B}$ ligand and osteoprotegerin in bone cell biology. $J \mathrm{Mol} \mathrm{Med}$. 2001;79(5-6):243-253.

2. Wong BR, Josien R, Lee SY, Vologodskaia M, Steinman RM, Choi Y. The TRAF family of signal transducers mediates NF- $\kappa \mathrm{B}$ activation by the TRANCE receptor. J Biol Chem. 1998;273(43):28355-28359.

3. Boyce BF, Xing L. Biology of RANK, RANKL, and osteoprotegerin. Arthritis Res Ther. 2007;9(1):1.

4. Cheng ML, Fong L. Effects of RANKL-targeted therapy in immunity and cancer. Front Oncol. 2014;3:329.

5. Fata JE, Kong YY, Li J, et al. The osteoclast differentiation factor osteoprotegerin-ligand is essential for mammary gland development. Cell. 2000;103(1):41-50.

6. Hanada R, Leibbrandt A, Hanada T, et al. Central control of fever and female body temperature by RANKL/RANK. Nature. 2009;462(7272): 505-509.

7. Hanada R. The new function of RANKL/RANK system in the central nervous systems. Neurosci Res. 2011;71:e22.

8. Bucay N, Sarosi I, Dunstan CR, et al. Osteoprotegerin-deficient mice develop early onset osteoporosis and arterial calcification. Genes Dev. 1998;12(9):1260-1268.

9. Ndip A, Williams A, Jude EB, et al. The RANKL/RANK/OPG signaling pathway mediates medial arterial calcification in diabetic Charcot neuroarthropathy. Diabetes. 2011;60(8):2187-2196.

10. Osako MK, Nakagami H, Shimamura M, et al. Cross-talk of receptor activator of nuclear factor- $\mathrm{\kappa B}$ ligand signaling with renin-angiotensin system in vascular calcification. Arterioscler Thromb Vasc Biol. 2013; 33(6):1287-1296.

11. Coleman RE. Metastatic bone disease: clinical features, pathophysiology and treatment strategies. Cancer Treat Rev. 2001;27(3):165-176.

12. Schmiedel BJ, Scheible CA, Nuebling T, et al. RANKL expression, function, and therapeutic targeting in multiple myeloma and chronic lymphocytic leukemia. Cancer Res. 2013;73(2):683-694.

13. Delea TE, McKiernan J, Brandman J, et al. Impact of skeletal complications on total medical care costs among patients with bone metastases of lung cancer. J Thorac Oncol. 2006;1(6):571-576.

14. Lewis MA, Hendrickson AW, Moynihan TJ. Oncologic emergencies: pathophysiology, presentation, diagnosis, and treatment. CA Cancer J Clin. 2011;61(5):287-314.

15. Ibrahim T, Ricci M, Scarpi E, Bongiovanni A, Ricci R, Riva N. RANKL: a promising circulating marker for bone metastasis response. Oncol Lett. 2016;12:2970-2975.

16. Herzog CE. Overview of sarcomas in the adolescent and young adult population. J Pediatr Hematol Oncol. 2005;27(4):215-218.

17. Grimaud E, Soubigou L, Couillaud S, et al. Receptor activator of nuclear factor $\kappa \mathrm{B}$ ligand (RANKL)/osteoprotegerin (OPG) ratio is increased in severe osteolysis. Am J Pathol. 2003;163(5):2021-2031.

18. Lamoureux F, Richard P, Wittrant Y, et al. Therapeutic relevance of osteoprotegerin gene therapy in osteosarcoma: blockade of the vicious cycle between tumor cell proliferation and bone resorption. Cancer Res. 2007;67(15):7308-7318.

19. Chen Y, Di Grappa MA, Molyneux SD, et al. RANKL blockade prevents and treats aggressive osteosarcomas. Sci Transl Med. 2015; 7(317):317ra197.
20. Pearse RN, Sordillo EM, Yaccoby S, et al. Multiple myeloma disrupts the TRANCE/osteoprotegerin cytokine axis to trigger bone destruction and promote tumor progression. Proc Natl Acad Sci US A. 2001;98(20): 11581-11586.

21. Lewin J, Thomas D. Denosumab: a new treatment option for giant cell tumor of bone. Drugs Today (Barc). 2013;49(11):693-700.

22. Santini D, Perrone G, Roato I, et al. Expression pattern of receptor activator of NFKB (RANK) in a series of primary solid tumors and related bone metastases. J Cell Physiol. 2011;226(3):780-784.

23. Dougall WC. Molecular pathways: osteoclast-dependent and osteoclastindependent roles of the RANKL/RANK/OPG pathway in tumorigenesis and metastasis. Clin Cancer Res. 2012;18(2):326-335.

24. Gonzalez-Suarez E, Jacob AP, Jones J, et al. RANK ligand mediates progestin-induced mammary epithelial proliferation and carcinogenesis. Nature. 2010;468(7320):103-107.

25. Albany C, Hahn NM. Novel bone-targeting agents in prostate cancer. Prostate Cancer Prostatic Dis. 2014;17(2):112-118.

26. Kiesel L, Kohl A. Role of the RANK/RANKL pathway in breast cancer. Maturitas. 2016;86:10-16.

27. Tsubaki M, Takeda T, Yoshizumi M, Ueda E, Itoh T, Imano M. RANKRANKL interactions are involved in cell adhesion-mediated drug resistance in multiple myeloma cell lines. Tumour Biol. 2016;37(7): 9099-9110.

28. Nolan E, Vaillant F, Branstetter D, et al. RANK ligand as a potential target for breast cancer prevention in BRCA1-mutation carriers. Nat Med. 2016;22(8):933-939.

29. Azim HA, Peccatori FA, Brohée S, et al. RANK-ligand (RANKL) expression in young breast cancer patients and during pregnancy. Breast Cancer Res. 2015;17(1):24

30. Sigl V, Owusu-Boaitey K, Joshi PA, et al. RANKL/RANK control Brcal mutation-driven mammary tumors. Cell Res. 2016;26(7):761-774.

31. Zhang L, Teng Y, Fan Y, et al. The E3 ubiquitin ligase Cbl-b improves the prognosis of RANK positive breast cancer patients by inhibiting RANKL-induced cell migration and metastasis. Oncotarget. 2015;6(26): 22918-22933.

32. Schramek D, Leibbrandt A, Sigl V, et al. Osteoclast differentiation factor RANKL controls development of progestin-driven mammary cancer. Nature. 2010;468(7320):98-102.

33. Emery JG, McDonnell P, Burke MB, et al. Osteoprotegerin is a receptor for the cytotoxic ligand TRAIL. J Biol Chem. 1998;273(23): 14363-14367.

34. Holen I, Cross SS, Neville-Webbe HL, et al. Osteoprotegerin (OPG) expression by breast cancer cells in vitro and breast tumours in vivo - a role in tumour cell survival? Breast Cancer Res Treat. 2005;92(3):207-215.

35. Owen S, Ye L, Sanders AJ, Mason MD, Jiang WG. Expression profile of receptor activator of nuclear- $\mathrm{KB}$ (RANK), RANK ligand (RANKL) and osteoprotegerin (OPG) in breast cancer. Anticancer Res. 2013; 33(1):199-206.

36. Weichhaus M, Chung ST, Connelly L. Osteoprotegerin in breast cancer: beyond bone remodeling. Mol Cancer. 2015;14(1):117.

37. Tan W, Zhang W, Strasner A, et al. Tumour-infiltrating regulatory T cells stimulate mammary cancer metastasis through RANKL-RANK signalling. Nature. 2011;470(7335):548-553.

38. Palafox M, Ferrer I, Pellegrini P, et al. RANK induces epithelialmesenchymal transition and stemness in human mammary epithelial cells and promotes tumorigenesis and metastasis. Cancer Res. 2012; 72(11):2879-2888.

39. Tsubaki M, Komai M, Fujimoto SI, et al. Activation of NF- $\kappa$ B by the RANKL/RANK system up-regulates snail and twist expressions and induces epithelial-to-mesenchymal transition in mammary tumor cell lines. J Exp Clin Cancer Res. 2013;32:62.

40. Blake ML, Tometsko M, Miller R, Jones JC, Dougall WC. RANK expression on breast cancer cells promotes skeletal metastasis. Clin Exp Metastasis. 2014;31(2):233-245.

41. Pfitzner BM, Branstetter D, Loibl S, et al. RANK expression as a prognostic and predictive marker in breast cancer. Breast Cancer Res Treat. 2014;145(2):307-315. 
42. Fortner RT, Sarink D, Schock H, et al. Osteoprotegerin and breast cancer risk by hormone receptor subtype: a nested case-control study in the EPIC cohort. BMC Med. 2017;15:26.

43. Cuyàs E, Corominas-Faja B, Martín MM, et al. BRCA1 haplo insufficiency cell-autonomously activates RANKL expression and generates denosumab-responsive breast cancer-initiating cells. Oncotarget. 2017; 8(21):35019-35032.

44. Widschwendter M, Burnell M, Fraser L, et al. Osteoprotegerin (OPG), the endogenous inhibitor of receptor activator of NF- $\mathrm{B}$ ligand (RANKL), is dysregulated in BRCA mutation carriers. BioMedicine. 2015;2(10):1331-1339.

45. Reyes ME, Fujii T, Branstetter D, et al. Poor prognosis of patients with triple-negative breast cancer can be stratified by RANK and RANKL dual expression. Breast Cancer Res Treat. 2017;164(1):57-67.

46. Chen G, Sircar K, Aprikian A, Potti A, Goltzman D, Rabbani SA Expression of RANKL/RANK/OPG in primary and metastatic human prostate cancer as markers of disease stage and functional regulation. Cancer. 2006;107(2):289-298.

47. Holen I, Croucher PI, Hamdy FC, Eaton CL. Osteoprotegerin (OPG) is a survival factor for human prostate cancer cells. Cancer Res. 2002;62(6): 1619-1623.

48. Luo JL, Tan W, Ricono JM, et al. Nuclear cytokine-activated IKKo controls prostate cancer metastasis by repressing Maspin. Nature. 2007; 446(7136):690-694.

49. Odero-Marah VA, Wang R, Chu G, et al. Receptor activator of NF- $\kappa B$ ligand (RANKL) expression is associated with epithelial to mesenchymal transition in human prostate cancer cells. Cell Res. 2008;18(8): 858-870.

50. Miller RE, Roudier M, Jones J, Armstrong A, Canon J, Dougall WC. RANK ligand inhibition plus docetaxel improves survival and reduces tumor burden in a murine model of prostate cancer bone metastasis. Mol Cancer Ther. 2008;7(7):2160-2169.

51. Siampanopoulou M, El Mantani Ordoulidis S, Moustakas G, et al. The role of serum osteoprotegerin in metastatic prostate cancer - a case control study. Hippokratia. 2016;20(2):133-138.

52. Takayama K, Inoue T, Narita S, et al. Inhibition of the RANK/RANKL signaling with osteoprotegerin prevents castration-induced acceleration of bone metastasis in castration-insensitive prostate cancer Cancer Lett. 2017;397:103-110.

53. Chen LM, Kuo CH, Lai TY, et al. RANKL increases migration of human lung cancer cells through intercellular adhesion molecule-1 up-regulation. J Cell Biochem. 2011;112(3):933-941.

54. Curioni-Fontecedro A, Husmann L, Soldini D, Stahel RA. Primary non-small cell lung cancer response upon treatment with denosumab. Lung Cancer. 2013;82(3):506-508.

55. Miller RE, Jones JC, Tometsko M, Blake ML, Dougall WC. RANKL inhibition blocks osteolytic lesions and reduces skeletal tumor burden in models of non-small-cell lung cancer bone metastases. $J$ Thorac Oncol. 2014;9(3):345-354.

56. Mikami S, Katsube KI, Oya M, et al. Increased RANKL expression is related to tumour migration and metastasis of renal cell carcinomas. J Pathol. 2009;218(4):530-539.

57. Sasaki A, Ishikawa K, Haraguchi N, et al. Receptor activator of nuclear factor- $\kappa \mathrm{B}$ ligand (RANKL) expression in hepatocellular carcinoma with bone metastasis. Ann Surg Oncol. 2007;14(3):1191-1199.

58. Jones DH, Nakashima T, Sanchez OH, et al. Regulation of cancer cell migration and bone metastasis by RANKL. Nature. 2006; 440(7084):692-696.

59. Khan IS, Mouchess ML, Zhu ML, et al. Enhancement of an anti-tumor immune response by transient blockade of central $\mathrm{T}$ cell tolerance. J Exp Med. 2014;211(5):761-768.

60. Heymann MF, Riet A, Le Goff B, Battaglia S, Paineau J, Heymann D. OPG, RANK and RANK ligand expression in thyroid lesions. Regul Pept. 2008;148(1-3):46-53.

61. Ito R, Nakayama H, Yoshida K, et al. Expression of osteoprotegerin correlates with aggressiveness and poor prognosis of gastric carcinoma. Virchows Arch. 2003;443(2):146-151.
62. Mizutani Y, Matsubara H, Yamamoto K, et al. Prognostic significance of serum osteoprotegerin levels in patients with bladder carcinoma. Cancer. 2004;101(8):1794-1802.

63. Cui X, Peng H, Jin J, et al. RANK overexpression as a novel esophageal cancer marker: validated immunohistochemical analysis of two different ethnicities. Int J Clin Exp Pathol. 2015;8(2):2249-2258.

64. Schmiedel BJ, Grosse-Hovest L, Salih HR. A "vicious cycle" of NKcell immune evasion in acute myeloid leukemia mediated by RANKL? Oncoimmunology. 2013;2(5):e23850.

65. Su T, Li J, Meng M, et al. Bone marrow stromal cells induced activation of nuclear factor $\mathrm{\kappa B}$ signaling protects non-Hodgkin's B lymphoma cells from apoptosis. Tumour Biol. 2016;37(8):10745-10752.

66. Schmohl JU, Nuebling T, Wild J, Kroell T, Kanz L, Salih HR. Expression of RANK-L and in part of PD-1 on blasts in patients with acute myeloid leukemia correlates with prognosis. Eur J Haematol. 2016;97(6):517-527.

67. Kostenuik PJ, Nguyen HQ, McCabe J, et al. Denosumab, a fully human monoclonal antibody to RANKL, inhibits bone resorption and increases BMD in knock-in mice that express chimeric (murine/human) RANKL. J Bone Miner Res. 2009;24(2):182-195.

68. Peddi P, Lopez-Olivo MA, Pratt GF, Suarez-Almazor ME. Denosumab in patients with cancer and skeletal metastases: a systematic review and meta-analysis. Cancer Treat Rev. 2013;39(1):97-104.

69. Palmerini E, Chawla NS, Ferrari S, et al. Denosumab in advanced/ unresectable giant-cell tumour of bone (GCTB): for how long? Eur J Cancer. 2017;76:118-124.

70. van der Heijden L, Dijkstra PDS, Blay JY, Gelderblom H. Giant cell tumour of bone in the denosumab era. Eur J Cancer. 2017;77:75-83.

71. Nolan E, Vaillant F, Branstetter D, et al. RANK ligand as a potential target for breast cancer prevention in BRCA1-mutation carriers. Nat Med. 2016;22(8):933-939.

72. Heath DJ, Vanderkerken K, Cheng X, et al. An osteoprotegerin-like peptidomimetic inhibits osteoclastic bone resorption and osteolytic bone disease in myeloma. Cancer Res. 2007;67(1):202-208.

73. Kim H, Choi HK, Shin JH, et al. Selective inhibition of RANK blocks osteoclast maturation and function and prevents bone loss in mice. J Clin Invest. 2009;119(4):813-825.

74. Téletchéa S, Stresing V, Hervouet S, et al. Novel RANK antagonists for the treatment of bone-resorptive disease: theoretical predictions and experimental validation. J Bone Miner Res. 2014;29(6):1466-1477.

75. Zhao Y, Jin M, Ma J, et al. Inhibition effect of enteropeptidase on RANKL-RANK signalling by cleavage of RANK. FEBS Lett. 2013; 587(18):2958-2964.

76. Naidu VG, Babu KR, Thwin MM, Satish RL, Kumar PV, Gopalakrishnakone P. RANKL targeted peptides inhibit osteoclastogenesis and attenuate adjuvant induced arthritis by inhibiting NF- $\kappa \mathrm{B}$ activation and down regulating inflammatory cytokines. Chem Biol Interact. 2013;203(2):467-479.

77. Ma R, Xu J, Dong B, Kauther MD, Jäger M, Wedemeyer C. Inhibition of osteoclastogenesis by RNA interference targeting RANK. $B M C$ Musculoskelet Disord. 2012;13:154.

78. Brennan TC, Rybchyn MS, Green W, Atwa S, Conigrave AD, Mason RS. Osteoblasts play key roles in the mechanisms of action of strontium ranelate. Br J Pharmacol. 2009;157(7):1291-1300.

79. Xiu Y, Xu H, Zhao C, et al. Chloroquine reduces osteoclastogenesis in murine osteoporosis by preventing TRAF3 degradation. J Clin Invest. 2014;124(1):297-310.

80. Ma X, Liu Y, Zhang Y, Yu X, Wang W, Zhao D. Jolkinolide B inhibits RANKL-induced osteoclastogenesis by suppressing the activation NF- $\kappa \mathrm{B}$ and MAPK signaling pathways. Biochem Biophys Res Commun. 2014;445(2):282-288.

81. Ha H, Shim KS, Kim T, et al. Water extract of Acer tegmentosum reduces bone destruction by inhibiting osteoclast differentiation and function. Molecules. 2014;19(4):3940-3954.

82. Ihn HJ, Kim JA, Bae YC, Shin HI, Baek MC, Park EK. Afatinib ameliorates osteoclast differentiation and function through downregulation of RANK signaling pathways. BMB Rep. 2017;50(3):150-155. 


\section{Publish your work in this journal}

OncoTargets and Therapy is an international, peer-reviewed, open access journal focusing on the pathological basis of all cancers, potential targets for therapy and treatment protocols employed to improve the management of cancer patients. The journal also focuses on the impact of management programs and new therapeutic agents and protocols on

patient perspectives such as quality of life, adherence and satisfaction. The manuscript management system is completely online and includes a very quick and fair peer-review system, which is all easy to use. Visit http://www.dovepress.com/testimonials.php to read real quotes from published authors.

Submit your manuscript here: http://www.dovepress.com/oncotargets-and-therapy-journal 